\title{
PENGEMBANGAN MODEL TAHAPAN LATIHAN SHOOTING TINGKAT DASAR DAN LANJUTAN UNTUK PEMAIN PETANQUE JAMBI
}

\author{
Rasyono $^{1}$, Sukendro ${ }^{2}$, Palmizal ${ }^{3}$ \\ Fakultas Ilmu Keolahragaan Universitas Jambi \\ rasyono@unja.ac.id ${ }^{1}$, sukendro@unja.ac.id ${ }^{2}$, palmizal@unja.ac.id ${ }^{3}$
}

\begin{abstract}
ABSTRAK
Tujuan penelitian ini adalah menghasilkan Produk Booklet Pedoman Tahapan Latihan Shooting Tingkat Dasar dan Lanjutan Untuk Pemain Petanque. Penelitian ini adalah penelitian pengembangan dengan metode model 4-D, yang terdiri dari 4 tahap dan akan dilaksanakan selama dua tahun, yaitu: (1) Define: menganalis permasalahan berbagai kajian teknik shooting pada para pemain petanque, (2) Design: Merancang Booklet, (3) Develop: pengembangan Booklet dengan validasi ahli dan uji coba kelompok kecil berupa respon pemain petanque, (4) Desseminate: penyebaran Booklet Pedoman latihan untuk pemain dan pelatih petanque. Hasil penelitian draf I: (1) validasi ahli menunjukan untuk seluruh aspek diperoleh rata-rata 4,04 mendapat penilaian baik dengan kriteria kevalidan dikategorikan valid. (2) validasi materi menunjukkan bahwa untuk seluruh aspek penilaian diperoleh rata-rata 4,17 mendapat penilaian baik dengan kriteria kevalidan dikategorikan valid. Hasil penelitian draf II: (1) penilaian respon pemain terhadap booklet seluruh aspek penilaian diperoleh rata-rata 4,18 dengan penilaian setuju dan kriteria kepraktisan adalah praktis. (2) penilaian pelatih petanque terhadap seluruh aspek diperoleh rata-rata 4,16 dengan penilaian setuju dan kriteria kepraktisan adalah praktis.
\end{abstract}

Kata Kunci: Petanque; booklet, shooting, latihan

\section{DEVELOPMENT OF BASIC AND ADVANCED SHOOTING STAGE EXERCISE MODELS FOR PETANQUE JAMBI PLAYERS}

\begin{abstract}
The purpose of this study was to produce a Basic and Advanced Level Booklet for the Shooting Practice Booklet for Petanque Players. This research is a research development with a 4-D model method, which consists of 4 stages and will be carried out for two years, namely: (1) Define: analyzing the problems of various shooting techniques studies on petanque players, (2) Design: Designing Booklets, (3) Develop: the development of a Booklet with expert validation and small group trials in the form of petanque player responses, (4) Desseminate: distribution of Exercise Training Booklets for petanque players and coaches.

The results of the research draft I: (1) expert validation shows for all aspects obtained an average of 4.04 got a good rating with validity criteria categorized valid. (2) material validation shows that for all aspects of the assessment obtained an average of 4.17 got a good rating with validity criteria categorized valid. The results of the draft research II: (1) assessment of player responses to booklets for all aspects of the assessment obtained an average of 4.18 with agreed ratings and practical criteria are practical. (2) the assessment of petanque trainers on all aspects obtained an average of 4.16 with an agreed rating and practicality criteria were practical.
\end{abstract}

Keywords: Petanque; booklet; shooting; practice.

Dipublikasikan Oleh :

UPT Publikasi dan Pengelolaan Jurnal

Universitas Islam Kalimantan Muhammad Arsyad Al-Banjari Banjarmasin 


\section{PENDAHULUAN}

Olahraga merupakan sebuah disiplin ilmu yang sangat kom plek karena bukan saja mempelajari tentang aktivitas fisik melainkan lebih dari itu yakni mempelajrai semua spek yang mempengaruhi aspek fisik tersebut. Kajian-kajian yang mempengaruhi aspek fisik dikaji dalam berbagai disiplin ilmu yang berhubungan dengan faal, anatomi, teori latihan, belajar gerak dan banyak hal lain lagi.

Belajar gerak dalam olahraga khusunya cabang olahraga selalu berhubungan dengan bagaimana seseorang pemain atau atlet dapat menguasai suatu teknik yang baik dan benar. Untuk dapat melakukan teknik gerakan yang baik dan benar harus dilakukan latihan yang benar juga. Latihan dikatan baik dan benar jika dilakukan dengan menganut prinsip-prinsip latihan dan mengacu pada teori belajar gerak.

Proses belajar maupun latihan harus dilakukan mulai dari yang sederhana menuju pada sesuatu yang kompleks, dari yang mudah menuju pada yang sulit dan dari yang dilakukan bagian per bagian kepada yang dilakukan menyeluruh atau rangkaian. Latihan sebagai bagaian dari sebuah proses belajar motorik juga harus dilakukan secara bertahap sesuai dengan level maupun tingkatan kemampauan seseorang. Secara sistematis dapat digambarkan, bahwa jika kita belajar dan berlatih maka kita tidak pernah sama dengan keadaan sebelumnya. Belajar dan berlatih akan menghasilkan perubahan yang relatif permanen. Hasil latihan gerak maupun teknik akan berdampak pada gerakan yang permanen dikemudian hari.

Olahraga Petanque yang telah sangat berkembang di dunia dan Indonesia serta Jambi pada khususnya merupakan salah satu disiplin olahraga yang bertitik berat pada rumpun olahraga yang sangat mengedepankan akurasi. Hal ini ditandai bahwa dominan permianan cabang olahraga ini adalah dengan cara melempar bola mendekati sasaran ataupun menjauhkan bola lawan dari sasaran dengan cara melakukan shooting. Shooting merukapan sebuah teknik yang paling dominan harus dimiliki oleh semua pemain petanque. Shooting yang baik akan dapat menghasilkan point yang banyak dan bisa memenangkan pertandingan.

Akurasi shooting akan didapatkan jika dilatih dengan menggunakan teknik yang benar. Teknik yang benar bisa didapatkan oleh para pemain dengan proses latihan yang baik, terarah, kontinyu dan dilakukan secara bertahap. Akurasi yang baik juga akan sangat dipengaruhi oleh penguasaan proses belajar yang baik dari tahap koognitif, asosiatif dan otomatisasi. Gerak otomatisasi bisa didapatkan jika pemain tidak lagi melakukan kesalahan dari segi teknik. Untuk mendapatkan gerakan ini latihan yang dilakukan harus memenuhi kriteria yang latihan yang dilakukan harus terarah dan memiliki rujukan yang baik.

Gambaran sebuah proses latihan menuju tingkat akurasi di atas menjadi dasar kuat penelitian ini untuk dapat menghasilkan sebuah panduan berupa Booklet tentang "Tahapan Latihan Shooting Tingkat Dasar dan Lanjutan Untuk Pemain Petanque Jambi”.

\section{Definisi Olahraga Petanque}

Petanque adalah permainan sederhana. Tujuan dari permainan ini adalah untuk melempar bola besi (bosi) sehingga dekat dengan sasaran (boka/bola kayu). Seorang pemain atau tim memiliki skor atau poin dengan memiliki satu atau lebih dari bosi mereka lebih dekat ke boka dari posisi bosi lawan setelah semua bosi telah dilemparkan. Pemenangnya adalah pemain pertama atau tim untuk mencapai 13 poin.

Petanque is the world's most egalitarian sport. It can be savoured by almost anyone, regardless of age, gender or physical constraints (B.W Putman, 2011). Petanque merupakan olahraga yang sangat berkembang dan bias dimainkan oleh sega usia, jenis kelamin dan tanpa mempertimbangkan fisik khusus. Namun utuk menjadi seorang pemain yang bagus diperlukan penguasaan teknik yang baik. Technique and the training process is where we"re going to start. Technique is obviously the basis on which everything is built (Gilles Souef, 2015:29). Berikut adalah sekilas tentang teknid dasar bermain petanque.

\section{Teknik Dasar Olahraga Petanque}

\section{Lemparan Menuju Titik Sasaran/Pointing (Throwing for pointing)}

Ponter/ Mendekati adalah aksi dimana pemain melempar bosi dengan tujuan mendekati posisi sasaran seperti menempatkan bosi disuatu tempat tertentu yakni dekat dengan boka, didepan bosi lawan dan sebaginya dengan tujuan menghalangi atau mengambil point (Vernet, Cedrik. 2019:22). Ponting biasanya dilakukan dengan jongkok namun itu tergantung dari kenyamanan pemian. Berikut Adalah jenis-jenis teknik ponting :

1) Roll ( Lemparan dengan menggelindingkan bola ke tanah)

Teknik lemparan dengan cara menggelindingkan bola menyusur tanah tanpa adanya lemparan melambung.Biasanya teknik ini dipakai dilapangan yang terbuat dari pasir ataupun batu kerikil kecil dan berjenis tanah keras. 

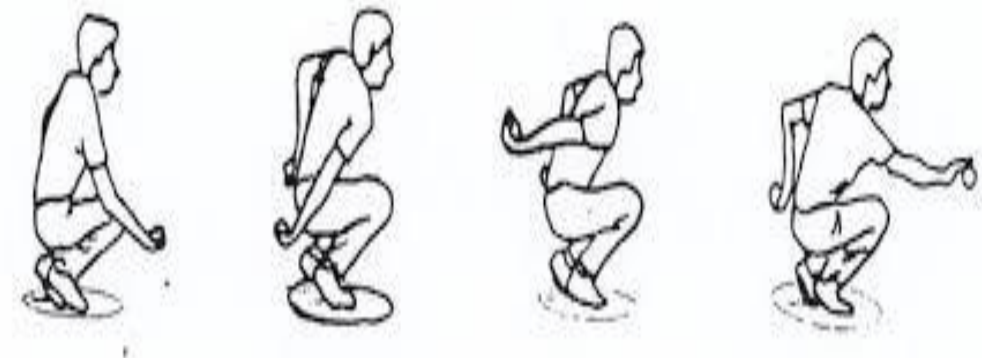

Gambar 1. Pointing Roll (Gesur)

(Sumber: F.I.P.J.P and LE C.I.E.P, 2006:5-8)

2) Soft-Lob ( Lemparan Setengah Parabol)

Teknik lemparan dengan cara melempar bola sedikit melambung diudara. Biasanya teknik ini digunakan dilapangan yang berjenis tanah keras dan berbatu kerikil kecil.

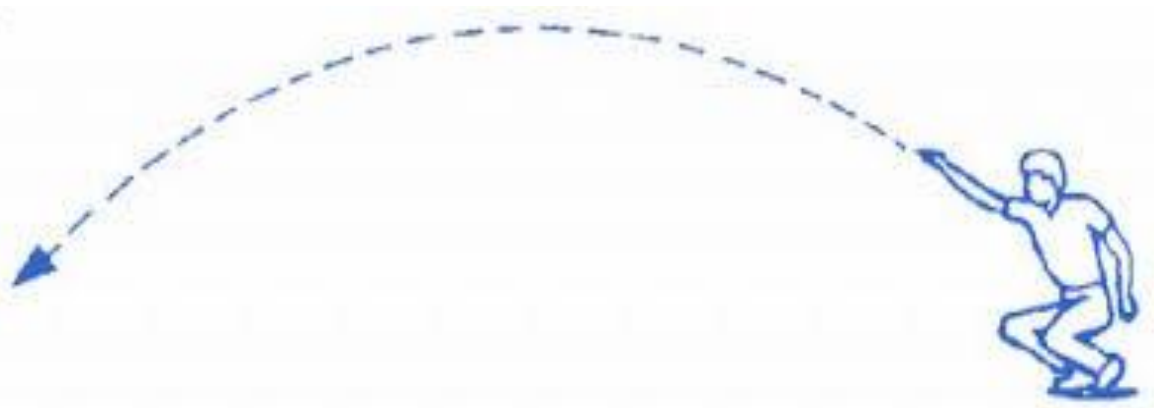

Gambar 2. Pointing soft-lob

(Sumber: F.I.P.J.P and LE C.I.E.P, 2006:5-8)

3) High-Lob (Lemparan Tinggi Parabol)

Teknik lemparan dengan cara melempar bola melambung tinggi diudara. Biasanya teknik ini digunakan dilapangan yang berjenis tanah basah, berpasir, dan berkerikil kecil.

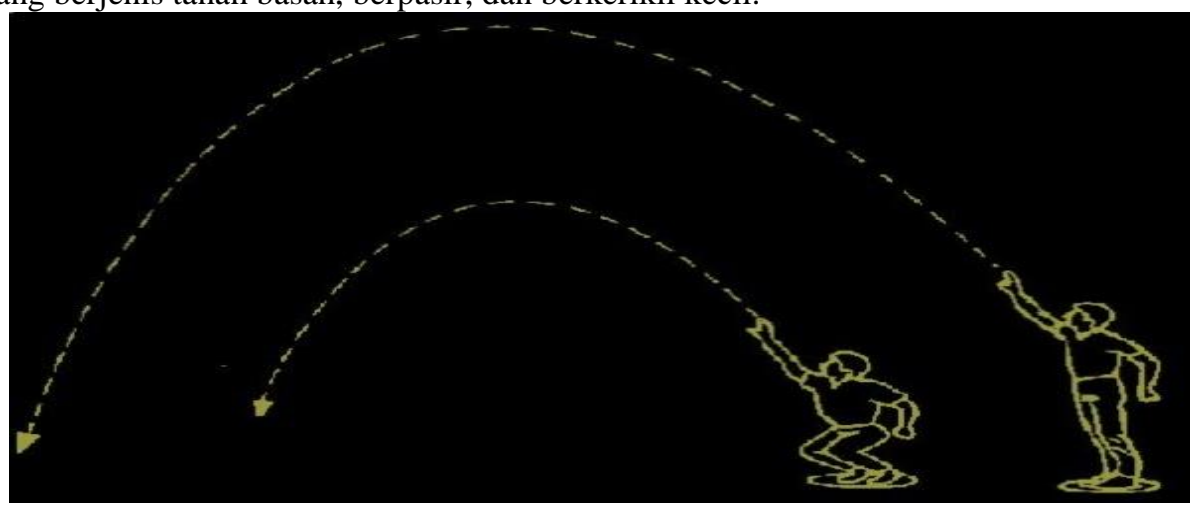

Gambar 3. Pointing High lob

(Sumber: F.I.P.J.P and LE C.I.E.P, 2006:5-8)

\section{Lemparan untuk menembak (Throwing for shooter)}

Shooting adalah jenis lemparan untuk mengusir bosi lawan dari boka target. Shooting atau menembak adalah melempar bosi dengan tujuan mengenai sasaran yakni bosi lawan untuk menjauhkan serta boka untuk menjadikan boka mati atau permainan selesai (Vernet, Cedrik. 2019:28). Ada beberapa cara melakukan Shooting, yaitu:

Dipublikasikan Oleh : 


\section{1) Shot On The Iron}

Salah satu jenis Shooting yang perkenanan nya langsung presentuhan bola besi dengan bola besi tanpa menyentuh tanah terlebih dahulu.

2) Short Shot

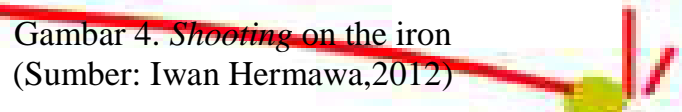

Salah satu jenis Shooting dimana bola yang dilemparkan terlebih dahulu menyentuh tanah dekat dengan bola sasaran sebelum menyentuh atau mengenai bola sasaran.

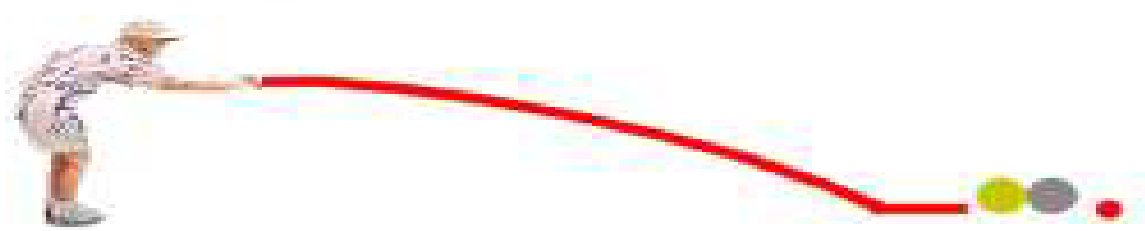

Gambar 5. Short Shooting

(Sumber : Iwan Hermawan, 2012)

3) Ground Shot

Salah satu jenis Shooting dimana bola yang dilemparkan terlebih dahulu menyentuh tanah jauh dengan bola sasaran sebelum menyentuh atau mengenai bola sasaran.

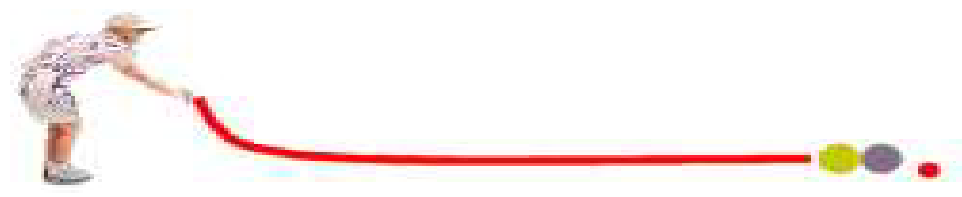

Gambar 6. Shooting Ground shot

(Sumber: Iwan Hermawan, 2012)

\section{Definisi dan Prinsip-Prinsip Latihan}

Latihan adalah aktivitas olahraga yang sistematik dalam waktu yang lama, ditingkatkan secara progresif dan individual yang mengarah kepada ciri-ciri fungsi fisiologis dan psikologis manusia untuk mencapai sasaran yang telah ditentukan (Bompa 1994: 4). Menurut Sukadiyanto, (2011: 1) latihan merupakan suatu proses perubahan kearah lebih baik, yaitu untuk meningkatkan kualitas fisik, kemampuan fungsional peralatan tubuh, dan kualitas psikis anak latih. Sedangkan menurut Hare yang dikutip oleh Dwi Hatmisari Ambarukmi dkk, (2007 : 1) latihan (training) olahraga adalah proses penyempurnaan berolahraga melalui pendekatan ilmiah yang berdasarkan prinsip-prinsip latihan, secara teratur dan terencana sehingga mempertinggi kemampuan dan kesiapan olahragawan.

Latihan sebagai suatu proses penyempurnaan kemampuan berolahraga yang berisi materi teori dan praktek, menggunakan metode, dan aturan pelaksanaan dengan pendekatan ilmiah, memakai prinsip pendidikan yang terencana dan teratur, sehingga tujuan latihan dapat tercapai pada waktunya. Latihan yang baik selalu mengacu pada prinsip-prinsip dasar dalam berlatih. Adapun prinsip-prinsip latihan menurut Bompa meliputi : partisipasi aktif, Perkembangan menyeluruh, Spesialisasi, Individualisasi, Variasi, Model dalam proses latihan, Beban meningkat. Lalu menurut Fleck dan Kraemer prinsip-prinsip latihan meliputi : Pembebanan berlebih, Waktu istirahat, Kekhususan, Variasi latihan, Detraining, Individualisasi.

\section{Definisi Buku Pedoman}

Buku adalah buah pikiran yang berisi ilmu pengetahuan hasil analisis terhadap kurikulum secara tertulis. Buku disusun menggunakan bahasa sederhana, menarik, dan dilengkapi gambar serta daftar pustaka (Kurniasih, 2014: 60). Menurut Tim Dirjen Dikdasmen (dalam Andi Prastowo, 2014:243), buku merupakan bahan tertulis yang menyajikan ilmu pengetahuan buah pikiran dari pengarangnya.

\section{Dipublikasikan Oleh :}


Buku pedoman sering disebut sebagai hand book, buku panduan, buku penuntun, dan buku pegangan. Effendy mengatakan bahwa buku pedoman adalah, "Buku yang berisi informasi, petunjuk, dan lain-lain yang menjadi petunjuk tuntunan bagi pembaca untuk mengetahui sesuatu secara lengkap". untuk memperoleh berbagai informasi yang dibutuhkan dalam buku pedoman sebagai penuntun selama beraktifitas dalam ruang lingkup tertentu, maka pembaca bukan sekadar mengetahui, mengerti, dan memahami, namun dilanjutkan pada tahap perbuatan.

\section{Booklet}

Booklet adalah suatu media untuk menyampaikan pesan-pesan dalam bentuk tulisan dan gambar. Booklet sebagai saluran, alat bantu, sarana dan sumber daya pendukungnya untuk menyampaikan pesan harus menyesuaikan dengan isi materi yang akan disampaikan. Booklet menggambarkan sebuah informasi yang detail dan lugas langsung disertai gambar sehingga petunjuk atau informasi dari sebuah tahapan mudah dipahami. Booklet berupa buku berukuran kecil yang berisi tulisan dan gambar-gambar. Istilah booklet berasal dari buku dan leaflet, dimana media booklet merupakan perpaduan antara leaflet dengan buku atau sebuah buku dengan format kecil seperti leaflet. Struktur isinya seperti buku namun cara penyajian isinya jauh lebih singkat daripada sebuah buku.

\section{Kelebihan dan Manfaat Booklet}

Menurut Kemm dan Close dalam Aini (2010) booklet memiliki beberapa kelebihan yaitu: (1). Dapat dipelajari setiap saat, karena disain berbentuk buku. (2). Memuat informasi relatif lebih banyak dibandingkan dengan poster.

Menurut Ewles dalam Aini (2010), media booklet memiliki keunggulan sebagai berikut : (1). Klien dapat menyesuaikan dari belajar mandiri. (2). Pengguna dapat melihat isinya pada saat santai. (3). Informasi dapat dibagi dengan keluarga dan teman. (4). Mudah dibuat, diperbanyak dan diperbaiki serta mudah disesuaikan. (5). Mengurangi kebutuhan mencatat. (6). Dapat dibuat secara sederhana dengan biaya relatif murah. (7). Awet . (8). Daya tampung lebih luas. (9). Dapat diarahkan pada segmen tertentu.

Manfaat booklet sebagai media buku pedoman latihan adalah : (1). Menimbulkan minat sasaran pendidikan. (2). Membantu di dalam mengatasi banyak hambatan. (3). Membantu sasaran pendidikan untuk belajar lebih banyak dan cepat. (4). Merangsang sasaran pendidikan untuk meneruskan pesan-pesan yang diterima kepada orang lain. (5). Mempermudah penyampaian bahasa pendidikan. (6). Mempermudah penemuan informasi oleh sasaran pendidikan. (7). Mendorong keinginan orang untuk mengetahui lalu mendalami dan akhirnya mendapatkan pengertian yang lebih baik. (8). Membantu menegakkan pengertian yang diperoleh.

\section{Prinsip-prinsip Penyusunan Buku}

Depdiknas (2008:11) mengungkapkan "pengembangan booklet atau buku hendaknya memperhatikan prinsip-prinsip latihan berikut: (1) mulai dari yang mudah untuk memahami yang sulit, dari yang kongkret untuk memahami yang abstrak; (2) pengulangan memperkuat pemahaman; (3) umpan balik positif memberikan penguatan terhadap pemahaman siswa; (4) motivasi yang tinggi merupakan salah satu faktor penentu keberhasilan belajar; (5) mencapai tujuan; dan (6) mengetahui hasil yang dicapai”.

\section{METODE PENELITIAN \\ Model Pengembangan}

Metode yang digunakan dalam penelitian ini adalah penelitian dan pengembangan. Model yang digunakan dalam pengembangan booklet ini adalah pengembangan model 4-D. Model pengembangan 4-D (Four D) merupakan model pengembangan perangkat latihan. Model ini dikembangkan oleh S. Thiagarajan, Dorothy S. Semmel, dan Melvyn I. Semmel. Model pengembangan 4-D terdiri atas 4 tahap utama yaitu: Define (Pendefinisian), Design (Perancangan), Develop (Pengembangan) dan Disseminate (Penyebaran). Setiap tahap dalam pengembangan terdapat kegiatan-kegiatan yang harus dilakukan.

\section{Teknik Analisis Data}

1. Analisis Data Kevalidan Produk

Data kuantitatif yang diperoleh dari hasil penilaian ahli materi dan ahli desain disusun berdasarkan skala Likert (interval 1-5) seperti pada tabel berikut :

Tabel 1 Skor dan Kriteria Penilaian Ahli

\begin{tabular}{cc}
\hline Skor & Kriteria \\
\hline 5 & Sangat Baik \\
4 & Baik \\
\hline
\end{tabular}

Dipublikasikan Oleh : 


\begin{tabular}{lc}
\hline 3 & Cukup Baik \\
2 & Kurang Baik \\
1 & Sangat Kurang \\
\hline
\end{tabular}

Hasil angket validasi tersebut kemudian dianalisis dengan langkah-langkah sebagai berikut.

a. Menghitung rata-rata perolehan skor masing-masing aspek menggunakan rumus: $\bar{x}=\frac{\sum_{i=1}^{n} x_{i}}{n}$

Keterangan:

$\bar{x}=$ rata-rata skor

$x_{i}=$ skor ke $-\mathrm{i}$

$n=$ banyaknya keterangan pertanyaan

b. Skor rata-rata tersebut kemudian dikonversikan menjadi data kualitatif berdasarkan kriteria penilaian skala 5 (S. Eko Putro Widoyoko, 2009:238).

Tabel 2. Pedoman Konversi Skor Kualitatif

\begin{tabular}{cc}
\hline Interval & Kriteria \\
\hline $\bar{x}>\bar{x}_{i}+1,8 S b_{i}$ & Sangat Baik \\
$\mathrm{X}_{i}+0,6 S b_{i}<\bar{x} \leq \overline{\mathrm{x}}_{i}+1,8 S b_{i}$ & Baik \\
$\mathrm{X}_{i}-0,6 S b_{i}<\bar{x} \leq \overline{\mathrm{x}}_{i}+0,6 S b_{i}$ & Cukup Baik \\
$\mathrm{X}_{i}-1,8 S b_{i}<\bar{x} \leq \overline{\mathrm{x}}_{i}-0,6 S b_{i}$ & Kurang Baik \\
$\bar{x} \leq \overline{\mathrm{x}}_{i}-1,8 S b_{i}$ & Sangat Kurang \\
\hline
\end{tabular}

$\bar{x}_{i}=$ rerata ideal $=\frac{1}{2}($ skor maksimal ideal + skor minimal ideal $)$

$S b_{i}=$ simpangan baku $=\frac{1}{6}($ skor maksimal ideal - skor minimal ideal $)$

Skor maksimal ideal $=$ skor tertinggi $=5$

Skor minimal ideal $=$ skor terendah $=1$

Merujuk pada tabel 2 hasil penilaian oleh ahli dapat dikategorikan menjadi tabel 3

Tabel 3 Interval Kriteria Penilaian dan Kevalidan Booklet

\begin{tabular}{ccc}
\hline Rentang Skor & Kriteria & Kevalidan \\
\hline $\bar{x}>4,2$ & Sangat Baik & Sangat Valid \\
$3,4<\bar{x} \leq 4,2$ & Baik & Valid \\
$2,6<\bar{x} \leq 3,4$ & Cukup Baik & Cukup Valid \\
$1,8<\bar{x} \leq 2,6$ & Kurang Baik & Kurang Valid \\
$\bar{x} \leq 1,8$ & Sangat Kurang & Sangat Kurang Valid \\
\hline
\end{tabular}

2. Analisis Data Kepraktisan

Angket respons pemain bertujuan untuk mengetahui tanggapan pemain dan pelatih yang dapat dijadikan tolak ukur kualitas booklet yang telah dikembangkan dari aspek kepraktisan. Dalam angket respons ini terdapat lima pilihan jawaban dengan kriteria penilaian sebagai berikut.

Tabel 4 Skala Penilaian Respon Pemain dan Pelatih

\begin{tabular}{cc}
\hline Kategori & Skor \\
\hline Sangat Setuju & 5 \\
Setuju & 4 \\
Cukup Setuju & 3 \\
Kurang Setuju & 2 \\
Sangat Kurang Setuju & 1 \\
\hline
\end{tabular}

Analisis kepraktisan dilakukan dengan langkah-langkah yang sama dengan analisis kevalidan. Interval kriteria kepraktisan ditinjau dari angket respons pemain dan pelatih dijelaskan pada tabel berikut :

Tabel 5. Kriteria Kepraktisan Booklet dari Angket Respons pemain dan pelatih

\begin{tabular}{ccc}
\hline Rentang Skor & Kriteria & Kevalidan \\
\hline $\bar{x}>4,2$ & Sangat Setuju & Sangat Praktis \\
$3,4<\bar{x} \leq 4,2$ & Setuju & Praktis \\
\hline
\end{tabular}

Dipublikasikan Oleh: 


\begin{tabular}{ccc}
\hline $2,6<\bar{x} \leq 3,4$ & Cukup Setuju & Cukup Praktis \\
$1,8<\bar{x} \leq 2,6$ & Kurang Setuju & Kurang Praktis \\
$\bar{x} \leq 1,8$ & Sangat Kurang Setuju & Sangat Kurang Praktis \\
\hline
\end{tabular}

\section{HASIL DAN PEMBAHASAN}

Hasil Penelitian Draf I

Validasi booklet oleh ahli bertujuan untuk melihat isi produk yang dikembangkan sebelum melakukan uji coba. Adapun kegiatan validasi yang dilakukan dengan cara memberikan booklet dan lembar angket beserta lembar validasi kepada kedua orang validator ahli yaitu: (1) validator desain; (2) validator materi;

\section{1) Hasil Validasi Ahli Desain terhadap Booklet}

Skor hasil validasi desain terhadap Booklet Latihan shooting dianalisis dan di sajikan pada tabel berikut

Tabel 6. Analisis Hasil Skor Validasi Ahli Desain terhadap Booklet Latihan shooting

\begin{tabular}{lcccccc} 
No & Aspek Penilaian & $\begin{array}{c}\text { Skor yang } \\
\text { diperoleh }\end{array}$ & $\begin{array}{c}\text { Banyak } \\
\text { pertanyaan }\end{array}$ & $\begin{array}{c}\text { Rata- } \\
\text { rata }\end{array}$ & $\begin{array}{c}\text { Kriteria } \\
\text { Keteranga } \\
\text { n }\end{array}$ & \\
\hline 1 & Tampilan tulisan & 28 & 7 & 4 & Baik & Valid \\
2. & Tampilan Gambar & 20 & 5 & 4 & Baik & Valid \\
3. & Desain & 24 & 6 & 4 & Baik & Valid \\
4. & Format & 21 & 5 & 4,2 & Baik & Valid \\
& Jumlah & 93 & 23 & 4,04 & Baik & Valid \\
\hline
\end{tabular}

Berdasarkan analisis validasi ahli desain booklet Latihan shooting dengan aspek tampilan tulisan, tampilan gambar, desain dan format. Hasilnya menunjukkan keempat aspek mendapat penilaian baik dengan kriteria kevalidan dikategorikan valid, sedangkan untuk seluruh aspek diperoleh rata-rata 4,04 juga mendapat penilaian baik dengan kriteria kevalidan dikategorikan valid.

2) Hasil Validasi Ahli Materi terhadap Booklet Latihan shooting

Skor hasil validasi ahli materi terhadap Booklet Latihan shooting dianalisis dan di sajikan pada tabel berikut

Tabel 7. Analisis Skor Hasil Validasi Ahli Materi terhadap Booklet Latihan shooting

\begin{tabular}{|c|c|c|c|c|c|c|}
\hline No & Aspek Penilaian & $\begin{array}{l}\text { Skor yang } \\
\text { diperoleh }\end{array}$ & $\begin{array}{l}\text { Banyak } \\
\text { pertanyaan }\end{array}$ & $\begin{array}{l}\text { Rata- } \\
\text { rata }\end{array}$ & Kriteria & Kevalidan \\
\hline 1 & Kelayakan Isi & 26 & 6 & 4,33 & Sangat Baik & Sangat Valid \\
\hline 2. & $\begin{array}{l}\text { Ketepatan } \\
\text { Cakupan Isi }\end{array}$ & 12 & 3 & 4 & Baik & Valid \\
\hline 3. & Ketercernaan & 12 & 3 & 4 & Baik & Valid \\
\hline 4. & $\begin{array}{l}\text { Penggunaan } \\
\text { Bahasa }\end{array}$ & 12 & 3 & 4 & Baik & Valid \\
\hline \multirow[t]{2}{*}{5.} & Perwajahan & 13 & 3 & 4,33 & Sangat Baik & Sangat Valid \\
\hline & Jumlah & 75 & 18 & 4,17 & Baik & Valid \\
\hline
\end{tabular}

Berdasarkan analisis validasi ahli materi booklet Latihan shooting dengan aspek ketepatan cangkupan isi, ketercematan dan penggunaan bahasa mendapat penilaian baik dengan kriteria kevalidan dikategorikan valid. Untuk aspek kelayakan isi dan perwajahan mendapat penilaian sangat baik dengan kriteria kevalidan dikategorikan sangat valid. Sedangkan untuk seluruh aspek penilaian diperoleh rata-rata 4,17 mendapat penilaian baik dengan kriteria kevalidan dikategorikan valid.

\section{Hasil Penelitian Draf II}

Uji coba kelompok kecil merupakan langkah pengembangan draf II, peneliti meminta respon dua orang pemain pentanque Jambi dan dua orang pelatih petanque Jambi.

\section{1) Hasil Angket Respon Pemain}

Hasil angket respons pemain terhadap Booklet di sajikan pada tabel berikut :

Tabel 8. Hasil Respon Pemain terhadap Booklet

Dipublikasikan Oleh : 


\begin{tabular}{|c|c|c|c|c|c|c|c|c|c|}
\hline \multirow{2}{*}{ Pemain } & \multicolumn{4}{|c|}{ Skor Diperoleh Peraspek Penilaian } & \multirow{2}{*}{$\sum x_{i}$} & \multirow{2}{*}{$N$} & \multirow{2}{*}{$\bar{x}$} & \multirow{2}{*}{ Kriteria } & \multirow{2}{*}{ Kepraktisan } \\
\hline & $\mathrm{I}$ & II & III & IV & & & & & \\
\hline AS & 17 & 39 & 33 & 16 & 105 & 25 & 4,2 & Setuju & Praktis \\
\hline FT & 16 & 40 & 32 & 16 & 104 & 25 & 4,16 & Setuju & Praktis \\
\hline$\sum x_{i}$ & 33 & 79 & 65 & 32 & 209 & 50 & 4,18 & Setuju & Praktis \\
\hline$N$ & 8 & 18 & 16 & 8 & 50 & & & & \\
\hline $\bar{x}$ & 4,12 & 4,38 & 4,06 & 4,00 & 4,18 & & & & \\
\hline Kriteria & Setuju & $\begin{array}{c}\text { SangatS } \\
\text { etuju }\end{array}$ & Setuju & Setuju & Setuju & & & & \\
\hline $\begin{array}{c}\text { Kepraktis } \\
\text { an }\end{array}$ & Praktis & $\begin{array}{l}\text { SangatP } \\
\text { raktis }\end{array}$ & Praktis & Praktis & Praktis & & & & \\
\hline $\begin{array}{l}\text { Keterangan } \\
\text { I : Desain } \\
\text { kelayakan } \\
\text { penilaian s } \\
\text { dengan krit } \\
\text { rata-rata 4, }\end{array}$ & $\begin{array}{l}\text { Latihan, II: } \\
\text { rdasarkan } \\
\text { isi, keterb } \\
\text { etuju deng } \\
\text { eria keprak } \\
8 \text { dengan }\end{array}$ & $\begin{array}{l}\text { Kelayakan } \\
\text { Analisis an } \\
\text { caan book } \\
\text { n kriteria }\end{array}$ & $\begin{array}{l}\text { si, III: Ket } \\
\text { ket respon } \\
\text { et dan vi } \\
\text { sepraktisan } \\
\text { sangat pra } \\
\text { uju dan kri }\end{array}$ & $\begin{array}{l}\text { rbacaan Ba } \\
\text { pemain te } \\
\text { ualisasi bc } \\
\text { adalah pra } \\
\text { tis. Sedan } \\
\text { ria keprak }\end{array}$ & $\begin{array}{l}\text { an Ajar dar } \\
\text { adap book } \\
\text { klet, has } \\
\text { is dan sat } \\
\text { an penilaia } \\
\text { an adalah }\end{array}$ & IV: V & $\begin{array}{l}\text { sualisas } \\
\text { an aspe } \\
\text { enunjuk } \\
\text { mendal }\end{array}$ & $\begin{array}{l}\text { ooklet } \\
\text { desain ped } \\
\text { n tiga as } \\
\text { penilaian }\end{array}$ & $\begin{array}{l}\text { an latihan, } \\
\text { mendapat } \\
\text { gat setuju } \\
\text { diperoleh }\end{array}$ \\
\hline
\end{tabular}

2) Hasil Respon Pelatih Petanque

Skor hasil angket respons pelatih petanque terhadap Booklet dianalisis dan di sajikan pada tabel berikut

Tabel 9. Hasil Respon Pelatih Petanque Terhadap Booklet Latihan shooting

\begin{tabular}{|c|c|c|c|c|c|c|c|c|c|}
\hline \multirow{2}{*}{ Pelatih } & \multicolumn{4}{|c|}{ Skor Diperoleh Per aspek Penilaian } & \multirow{2}{*}{$\sum x_{i}$} & \multirow[t]{2}{*}{$N$} & \multirow[t]{2}{*}{$\bar{x}$} & \multirow[t]{2}{*}{ Kriteria } & \multirow[t]{2}{*}{$\begin{array}{c}\text { Kepraktis } \\
\text { an }\end{array}$} \\
\hline & $\mathrm{I}$ & II & III & IV & & & & & \\
\hline SSF & 16 & 38 & 33 & 17 & 103 & 25 & 4,12 & Setuju & Praktis \\
\hline $\mathrm{E}$ & 17 & 39 & 32 & 18 & 105 & 25 & 4,2 & Setuju & Praktis \\
\hline$\sum x_{i}$ & 33 & 77 & 65 & 35 & 208 & 50 & 4,16 & Setuju & Praktis \\
\hline$N$ & 8 & 18 & 16 & 8 & 50 & & & & \\
\hline $\bar{x}$ & 4,12 & 4,27 & 4,06 & 4,37 & 4,16 & & & & \\
\hline Kriteria & Setuju & $\begin{array}{l}\text { SangatS } \\
\text { etuju }\end{array}$ & Setuju & $\begin{array}{l}\text { SangatS } \\
\text { etuju }\end{array}$ & Setuju & & & & \\
\hline $\begin{array}{l}\text { Kepraktis } \\
\text { an }\end{array}$ & Praktis & $\begin{array}{l}\text { Sangat } \\
\text { Praktis }\end{array}$ & Praktis & $\begin{array}{l}\text { SangatPr } \\
\text { aktis }\end{array}$ & Praktis & & & & \\
\hline
\end{tabular}

Keterangan:

I : Desain Latihan, II: Kelayakan Isi, III: Keterbacaan Booklet dan IV: Visualisasi Booklet

Berdasarkan analisis angket respon pelatih petanque terhadap booklet dengan aspek desain latihan, kelayakan isi, keterbacaan booklet dan visualisasi booklet, hasilnya menunjukkan dua aspek mendapat penilaian sangat setuju dengan kriteria kepraktisan adalah sangat praktis dan dua aspek mendapat penilaian setuju dengan kriteria kepraktisan adalah praktis. Sedangkan penilaian Pelatih petanque terhadap seluruh aspek diperoleh rata-rata 4,16 dengan penilaian setuju dan kriteria kepraktisan adalah praktis.

Hasil yang disampaikan di atas menujukkan bahwa dengan adanya Booklet Tahapan Latihan Shooting Tingkat Dasar dan Lanjutan Untuk Pemain Petanque Jambi sangat membantu dalam melatih bagi pelatih dan memudahkan pemahaman pemaint menganalisis secara mandiri kesalahan dalam latihan yang dilakukan. Selain

Dipublikasikan Oleh : 
itu hal utama dari hadirnya booklet ini adalah untuk menyadari batas kemampuan atlet sehingga materi latihan tidak berlebihan sesuai level dan kemampuan pemain tersebut. Gambaran tersebut sesuai dengan terori belajar gerak yakni belajar dari yang mudah ke yang sulit, dari yang sederhana sampai ke yang kompleks dan dari yang bagian perbagian sampai ke rangkaian penuh. Selanjutnya juga selaras dengan tahapan belajar gerak yakni tahap kognitif, tahap asosiatif dan tahap otomatisasi. Booklet ini sangat berguna memberikan pemahanan yang benar, latihan yang benar sehingga keterampilan serta kemampuan shooting pemain petanque akan berkembang dengan baik.

\section{PENUTUP}

\section{Kesimpulan}

1. Hasil penelitian draf I validasi ahli menunjukan untuk seluruh aspek diperoleh rata-rata 4,04 mendapat penilaian baik dengan kriteria kevalidan dikategorikan valid.

2. Hasil penelitian draf I validasi materi menunjukkan bahwa untuk seluruh aspek penilaian diperoleh ratarata 4,17 mendapat penilaian baik dengan kriteria kevalidan dikategorikan valid.

3. Hasil penelitian draf II penilaian respon pemain terhadap booklet seluruh aspek penilaian diperoleh rata-rata 4,18 dengan penilaian setuju dan kriteria kepraktisan adalah praktis.

4. Hasil penelitian draf II penilaian pelatih petanque terhadap seluruh aspek diperoleh rata-rata 4,16 dengan penilaian setuju dan kriteria kepraktisan adalah praktis.

\section{Saran}

Sebagai saran dalam penelitian ini, diperlukan penelitian lanjutan guna mengembangkan booklet menjadi buku sehingga bahasan serta cakupan lebih luas.

\section{REFERENSI}

Aini, F. 2010. Pengaruh Pendidikan Kesehatan Reproduksi Remaja Melalui Media Booklet Terhadap Perubahan Pengetahuan dan Sikap Santri Tentang Kesehatan Reproduksi di Pesantren Darul Hikmah dan Ta'dib Al Syakirim di Kota Medan Tahun 2010. Skripsi. Universitas Sumatera Utara ( USU ). Medan.

Ambarukmi, D.A.dkk. 2007. Pelatihan Pelatih FisikLevel I. Deputi Bidang Peningkatan Prestasi dan IPTEK Olahraga. Kemenpora.

B.W. Putman. 2011. PETANQUE The Greatest Game You Never Heard Of.

Bompa, Tudor. 1994. Theory and Methodology of Training. Kendal. Iowa: Hunt Publishing Company.

Departemen Pendidikan Nasional. 2008. Pengembangan Booklet dan Media. Jakarta: Departemen Pendidikan Nasional.FIPJP Petanque Rule 2017.

F.I.P.J.P and LE C.I.E.P. 2006. Pedagogical Leaflet. France: Plastico Rototech.

Gilles SOUEF. 2015. The Winning Trajectory : Petanque - Training and technique. France: Copymedia.

http://olahraga-petanque-cara-bermain-dan.html (diakses pada tanggal 24 februari 2017)

Iwan hermawan, M.Pd. 2012. Gerak dasar permainan olahraga Petanque. Jakarta : Deputi Pemberdayaan Olahraga.

Kurniasih,Sani. 2014. Strategi-Strategi Latihan. Bandung: Alfabeta.

Mulyatiningsih. 2014. Metode Penelitian Terapan Bidang Pendidikan. Yogyakarta: Alfabeta Bandung

Shirley Rosalina Lou Liat, Bing Bedjo Tanudjaja, Baskoro Suryo B. "Perancangan Buku Pedoman Olahraga Basket untuk Anak Usia 6-14 Tahun" . Jurnal DKV Adiwarna, Universitas Kristen Petra, Vol 1 No 2 2013.

Dipublikasikan Oleh :

UPT Publikasi dan Pengelolaan Jurnal

Universitas Islam Kalimantan Muhammad Arsyad Al-Banjari Banjarmasin 
Sukadiyanto . 2011. Pengantar Teori dan Metodologi Melatih Fisik. Bandung: CV Lubuk Agung.

Prastowo, Andi. 2012. Panduan Kreatif Membuat Booklet Inovatif. Yogyakarta: Diva Press.

Prastowo, Andi. 2015. Panduan Kreatif Membuat Booklet Inovatif, Menciptakan Metode Latihan yang Menarik dan Menantang. Yogyakarta: Diva Press.

Vernet, Cedrik. 2019. Olahraga Petanque: Petunjuk Pemain, Memo Wasit, Aturan Internasional. Jakarta: Kridatama Adara Konsep. 